\title{
MORPHOGENESIS OF MISCANTHUS × GIGANTEUS IN VITRO
}

\author{
O. L. Klyachenko, O. E. Nekrut \\ National University of Life and Environmental Sciences of Ukraine \\ 15, Heroiv Oborony Str., Kyiv, Ukraine 03041 \\ e-mail:Klyachenko@ukr.net,On27@ukr.net
}

Received on June 20, 2018

\begin{abstract}
Aim. To obtain planting material of Miscanthus $\times$ giganteus in a large amount in order to study the peculiarities of morphogenesis of isolated meristem culture. Methods. The explants were sterilized using $70 \%$ ethanol and $0.1 \%$ mercury bichloride, after that, the methods of plant cultivation and reproduction in vitro and statistical processing of the obtained data was performed. Results. The study presents the results of obtaining the regenerate plants from dormant buds of 3-year-old rhizomes of Miscanthus $\times$ giganteus. The Murashige and Skoog medium supplemented with 6-benzylaminopurine (BAP) $(0.75 \mathrm{mg} / \mathrm{L})$ and kinetin $(1.2 \mathrm{mg} / \mathrm{L}) \mathrm{was}$ found to be the best for regeneration of microsprouts, providing the maximum value of the regeneration index (95\%) and contributing to the development of the main sprouts and tillering. The obtained sprouts were rooted in Murashige and Skoog medium supplemented with half-dose of macro- and micronutrients without growth regulators. In doing so, rooting index made up 95.0-97.0\%. The best substrate for the adaptation of miscanthus plants in vivo was found to be a mixture of peat, sand, and perlite in a ratio of $2: 1: 1$, respectively. In this substrate, plant establishment reached $91 \%$. Conclusions. The peculiarities of morphogenesis in Miscanthus $\times$ giganteus isolated meristem were studied. At the same time, the index of sprouts regeneration varied from 90.0 to $100.0 \%$. In addition, the development of the main sprout and multiple tillering occurred in 85.0$100.0 \%$ explant. The highest survivability of micro-plants (91-95\%) was provided in the peat-sand-perlite substrate in a ratio of $2: 1: 1$.
\end{abstract}

Keywords: miscanthus, energy crop, regeneration, in vitro, morphogenesis.

DOI: $10.15407 /$ agrisp5.02.013

\section{INTRODUCTION}

One of the top priority tasks of all the civilized countries is ensuring the development of bioenergetics, preserving natural resources and searching for new sources of alternative energy. Recent years have witnessed a considerable interest to the new crop, Miscanthus $\times$ $\times$ giganteus, which is among the most promising plants to obtain biofuel of organic origin - ecologically pure and renewable source of energy [1]. By-products of plant origin (straw, corn stalks, etc.) and dedicated energy plants may also be used as energy commodity [2, $3]$. One of these plants is a tree-like grass - miscanthus. Miscanthus $\times$ giganteus, an allotriploid hybrid, remarkable for a considerably higher biomass gain compared to other species, is of the highest interest for biofuel

(C) O. L. KLYACHENKO, O. E. NEKRUT, 2018 production. This crop has a number of advantages compared to other energy crops: high biomass performance, positive energy balance, easy maintenance in soil, drought resistance [4].

Miscanthus $\times$ giganteus is a large warm-season Asian grass and a novel leading bioenergy crop in Asia, Europe and North America [5, 6]. The experience of Europe demonstrates that miscanthus has high biological performance of biomass in a wide geographical range of moderate climatic regions, including marginal lands $[7,8]$. It is not grown much in Ukraine yet, however, the interest to this energy crop is increasing consistently, as it can yield up to $20 \mathrm{t} /$ ha of dry matter in favorable weather conditions.

Many authors studied and developed novel biotechnological methods of reproducing miscanthus and elaborating new initial forms to enhance genetic variability 
KLYACHENKO et al.

Table 1. The impact of the culture medium composition on the development of Miscanthus $\times$ giganteus meristem cultures

\begin{tabular}{c|c|c|c|c}
\hline $\begin{array}{c}\text { No. of the } \\
\text { culture } \\
\text { medium }\end{array}$ & $\begin{array}{c}\text { Composition } \\
\text { of the culture medium }\end{array}$ & $\begin{array}{c}\text { Sprout length, } \\
\mathrm{mm}\end{array}$ & $\begin{array}{c}\text { Number of } \\
\text { sprouts, } \\
\text { it./explant }\end{array}$ & $\begin{array}{c}\text { Reproduction } \\
\text { coefficient }\end{array}$ \\
\hline MSR1 & MS $+\begin{array}{c}\text { BAP }(0.2 \mathrm{mg} / \mathrm{l})+\text { saccharose } \\
(30 \mathrm{mg} / \mathrm{l})\end{array}$ & $4.6 \pm 0.9$ & $2.8 \pm 0.5$ & $4.6 \pm 1.1$ \\
MSR2 & $\begin{array}{c}\mathrm{MS}+\mathrm{BAP}(0.75 \mathrm{mg} / \mathrm{l}) \text { and } \mathrm{kinetin} \\
(1.2 \mathrm{mg} / \mathrm{l})+\text { saccharose }(30 \mathrm{mg} / \mathrm{l})\end{array}$ & $13.3 \pm 1.0$ & $5.2 \pm 0.6$ & $11.4 \pm 1.2$ \\
\hline
\end{tabular}
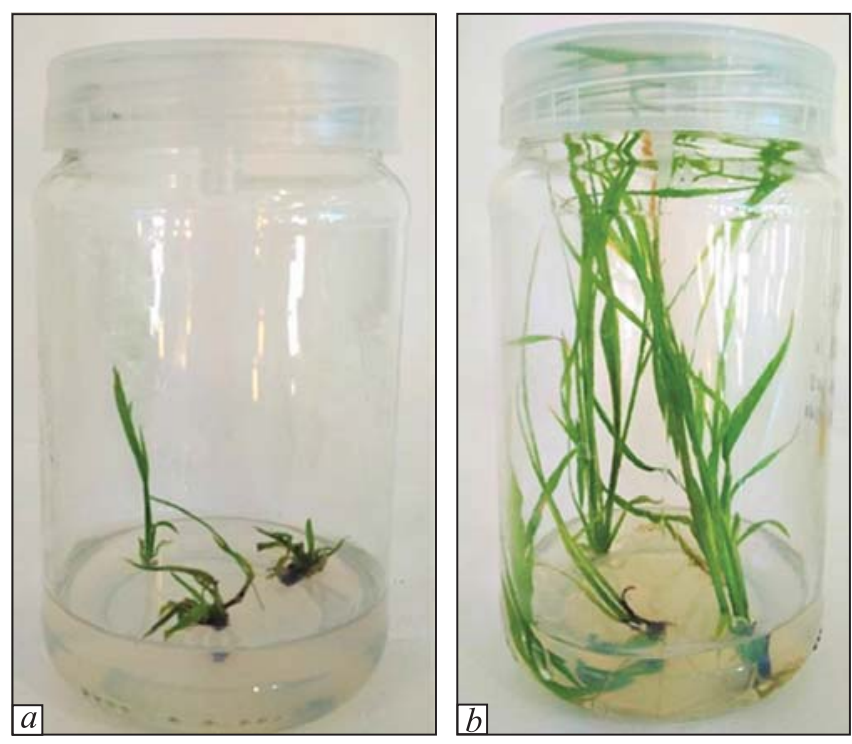

Fig. 1. The cultivation of miscanthus sprouts in the media of different composition ( $a-$ MSR1, $b-$ MSR2)

of current species from the standpoint of using them as bioenergetics commodity [9-11]. In order to accelerate the selection process, there are biotechnology methods, used to obtain a sufficient amount of material for studies in a short period of time [12]. Solving this problem is related to the search for the ways of direct morphogenesis in vitro in the culture medium and the possibility of regulating these ways in the controlled experimental conditions in vitro.

The aim of the work. To obtain planting material of Miscanthus $\times$ giganteus in a large amount in order to study the peculiarities of morphogenesis of isolated meristem culture.

\section{MATERIALS AND METHODS}

The material of the study was dormant buds of 3-yearold rhizomes of Miscanthus $\times$ giganteus. $70 \%$ ethanol and $0.1 \%$ solution of $\mathrm{HgCl}_{2}$ were used for sterilization. The explants were sterilized for $1.5 \mathrm{~min}$ in $70 \%$ ethanol and for $22 \mathrm{~min}$ in the solution of $0.1 \%$ mercury bichloride with subsequent washing in three portions of water for 7-10 min. Sterile explants were placed into tubes with $10 \mathrm{ml}$ Murashige and Skoog (MS) nonhormone culture medium [13] with subsequent transfer to the modified culture MS medium: MSR1 (MS + $+\operatorname{BAP}(0.2 \mathrm{mg} / \mathrm{l}))$ and MSR2 (MS + BAP $(0.75 \mathrm{mg} / \mathrm{l})+$ + kinetin $(1.2 \mathrm{mg} / \mathrm{l}))$. The biological replication was 40 plants.

Miscanthus sprouts were rooted in MS medium, supplemented with half-dose of macro- and microelements without growth regulators. The explants were cultivated in the cultural room at $23-25{ }^{\circ} \mathrm{C}$, relative air humidity of $60-70 \%$ and illumination of 3,000 lx, photoperiod $-16 \mathrm{~h}$. The plants were adapted to in vivo conditions in the climate chamber (Rubarth Apparate GmbH RUMED, Germany) using different soil mixtures: 1$)$ peat: sand : perlite $(2: 1: 1), 2)$ peat : sand $(2: 1), 3)$ peat : perlite : soil $(2: 2: 1)$ at 24 $25{ }^{\circ} \mathrm{C}$, humidity of $70-80 \%$, illumination intensity $1,500 \mathrm{~lx}$, photoperiod $-16 \mathrm{~h}$. The obtained results were statistically processed using Microsoft Office Excel 2010 package.

\section{RESULTS AND DISCUSSION}

Our studies demonstrated that the highest percentage of sterile dormant buds (70\%) was obtained by keeping them consistently in $70 \% \mathrm{C}_{2} \mathrm{H}_{5} \mathrm{OH}(1.5 \mathrm{~min})$ with further transfer into $0.1 \%$ solution of $\mathrm{HgCl}_{2}$ (22 min) and washing three times in sterile distilled water. The extracted dormant buds started enlarging on the $5^{\text {th }}-6^{\text {th }}$ day after planting into the culture medium. On days 8-10, they were transferred into the culture media MSR1 and MSR2. The efficiency of selected media was estimated by the following indices: the length of sprouts, their number and frequency of multiple tillering. The measurements of morphometric indices and the calculations of quantitative data were performed for 30 days (Table 1 ).

During the first three weeks of cultivation, the regeneration processes in isolated miscanthus plants were most active in the presence of a larger amount of BAP 
and kinetin in the culture medium. According to our observations, kinetin $(1.2 \mathrm{mg} / \mathrm{l})$ promoted the formation of buds and additional sprouts.

There is a known scientific fact that some cytokins are capable of removing apical domination and leading to awakening of accessory buds. In our studies the addition of BAP $(0.75 \mathrm{mg} / \mathrm{l})$ caused active formation of 3-7 additional sprouts on the $4^{\text {th }}-5^{\text {th }}$ week of cultivation. It should be noted that saccharose $(30 \mathrm{mg} / \mathrm{l})$ was found to be a favorable source of carbohydrates at this stage of cultivating isolated explants.

The studies demonstrated that the optimal culture medium for regeneration of microsprouts was MSR2, supplemented with BAP $(0.75 \mathrm{mg} / \mathrm{l})$ and kinetin $(1.2$ $\mathrm{mg} / \mathrm{l})$. Here the frequency of regeneration of sprouts was $90.0-100.0 \%$ with the development of the main sprout and multiple tillering with the frequency of $85.0-100.0 \%$ (Fig.1).

Noteworthy is the rhizogenesis process. The rooting of Miscanthus $\times$ giganteus sprouts in vitro depended on the size of a sprout and the number of passages performed. The 5-6-cm-long sprouts (8-9-week-old) were transferred to MS culture medium with half-dose of macro- and microelements without growth regulators. Miscanthus $\times$ giganteus plants demonstrated their capability of normal development in this culture medium. The formation of the root system was observed on the $8-11^{\text {th }}$ day of cultivation (Fig. 2).

After the formation of the root system, the laboratory plants started growing actively, doubling and even tripling in their sizes within 7 days with active formation of leaves. There were $4-10$ roots of $1.5 \mathrm{~cm}$ on average obtained per one sprout. On the $30^{\text {th }}$ day of cultivation the number of roots was in the range from 9 to 22 , and their length was from 4 to $13 \mathrm{~cm}$ (Table 2). The frequency of rooting was $95.0-97.0 \%$.
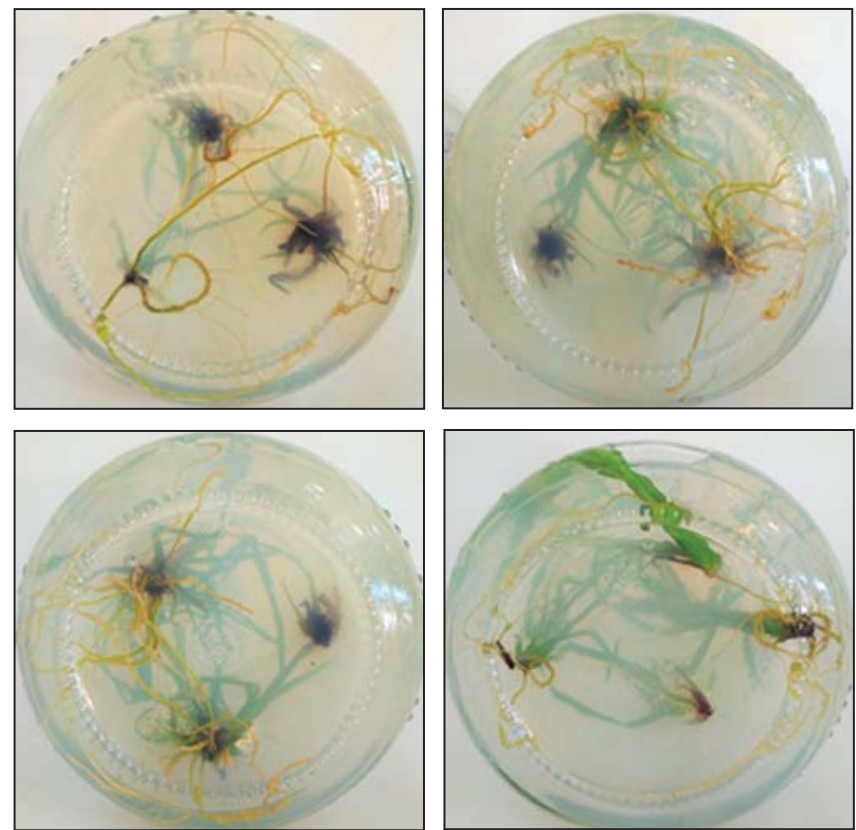

Fig. 2. The rhizogenesis of Miscanthus $\times$ giganteus

Table 2. The rooting of Miscanthus $\times$ giganteus in vitro

\begin{tabular}{c|c|c}
\hline Day & $\begin{array}{c}\text { Average number of } \\
\text { roots per plant, it. }\end{array}$ & $\begin{array}{c}\text { Average length } \\
\text { of roots, cm }\end{array}$ \\
\hline 10 & $6.3 \pm 0.3$ & $1.5 \pm 0.07$ \\
20 & $10.5 \pm 0.5$ & $4.3 \pm 0.2$ \\
30 & $14.1 \pm 0.7$ & $9.6 \pm 0.5$ \\
10 & $6.3 \pm 0.3$ & $1.5 \pm 0.07$ \\
\hline
\end{tabular}

The 12-14-week-old laboratory plants (depending on the cultivation period in the rooting medium) can be further grown in a greenhouse. Regenerate plants of 5-7 cm with a well-developed root system were carefully extracted with forceps, their roots were thoroughly washed from the culture medium (to prevent rotting and perishing of plants) and they were planted into different soil substrates.

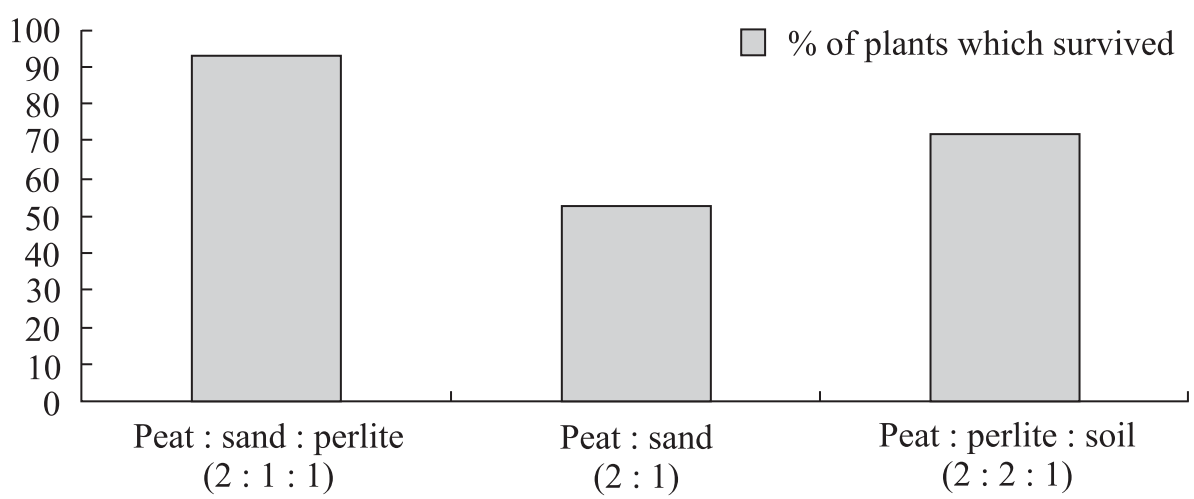

Fig. 3. The survivability of Miscanthus $\times$ giganteus regenerate plants in soil substrates 


\section{KLYACHENKO et al.}

Three different sterile substrates were used to adapt regenerate plants: No. 1 - peat:sand:perlite $(2: 1: 1)$; No. 2 - peat:sand (2:1); No. 3 - peat:perlite:soil (2:2:1) (Fig. 3). The plants were watered with distilled water regularly.

It is evident that substrate No. 1 was found to be the most efficient for miscanthus plants, as, contrary to substrates Nos. 2 and 3, it promoted fast rooting, growth and development of sprouts. Four-five weeks later the plants showed the formation of 3-4 leaves and fibroid root system. In these conditions the survivability of microplants was $91-95 \%$.

Therefore, a series of studies was conducted to investigate the peculiarities of morphogenesis of Miscanthus $\times$ giganteus isolated meristems.

\section{CONCLUSIONS}

The peculiarities of morphogenesis in Miscanthus $\times$ giganteus were studied in culture in vitro. The frequency of regeneration of sprouts was $90.0-100.0 \%$, there was noted development of the main sprout and multiple tillering with the frequency of $85.0-100.0 \%$. The most suitable substrate for adaptation of miscanthus to in vivo conditions was peat : sand : perlite in the ratio of $2: 1: 1$, the survivability of regenerate plants was $91-95 \%$.

\section{Морфогенез in vitro Miscanthus $\times$ giganteus \\ О. Л. Кляченко, О. Є. Некрут \\ e-mail: Klyachenko@ukr.net, On27@ukr.net \\ Національний університет біоресурсів і природокористування України \\ 15, вул. Героїв Оборони, м. Київ, Україна 03041}

Мета. Для отримання у великій кількості посадкового матеріалу міскантусу гігантського дослідити особливості морфогенезу в культурі ізольованих меристем Miscanthus $\times$ giganteus. Методи. Стерилізацію експланта-тів проводили використовуючи 70\%-ний розчин етилового спирту та $0,1 \%$-ний розчин сулеми. Надалі використовували методи культивування i розмноження рослин in vitro та статистичну обробку отриманих результатів. Результати. Наведено результати отримання рослинрегенерантів міскантусу зі сплячих бруньок, видалених із коренів трирічних рослин Miscanthus $\times$ giganteus. Оптимальним для регенерації мікропагонів виявилось живильне середовище Мурасіге-Скуга, доповнене 6бензиламінопурином та кінетином у концентрації 0,75 мг/л та 1,2 мг/л відповідно. При цьому частота регенерації пагонів була максимальною і становила $95 \%$, також спостерігався розвиток основного пагону та множинне пагоноутворення. Укорінення отриманих пагонів проводили на середовищі Мурасіге-Скуга 3 половинним вмістом макро- і мікроелементів без додавання регуляторів росту. Частота укорінення складала 95,0-97,0 \%. Для адаптації міскантусу до умов in vivo найкращим виявився субстрат торф : пісок : переліт у співвідношенні $2: 1$ : 1, при цьому приживлюваність рослин-регенерантів становила $91 \%$. Висновки. У результаті проведених досліджень вивчено особливості морфогенезу в культурі in vitro рослин міскантусу (Miscanthus $\times$ giganteus). Частота регенерації пагонів становила 90,0-100,0 \%, відбувався розвиток основного пагону і множинне пагоноутворення 3 частотою 85,0$100,0 \%$. Для адаптації міскантусу до умов in vivo найкращим виявився субстрат торф : пісок : перліт у співвідношенні 2:1:1, приживлюваність рослин-регенерантів становила 91-95\%.

Ключові слова: міскантус, енергетична культура, регенерація, in vitro, морфогенез.

\section{Морфогенез in vitro Miscanthus $\times$ giganteus \\ О. Л. Кляченко, О. Е. Некрут \\ e-mail: Klyachenko@ukr.net,on27@ukr.net \\ Национальный университет биоресурсов и природопользования Украины \\ 15, ул. Героев Обороны, г. Киев, Украина 03041}

Цель. Для получения в большом количестве посадочного материала мискантуса гигантского исследовали особенности морфогенеза в культуре изолированных меристем Miscanthus $\times$ giganteus. Методы. Стерилизацию эксплантатов проводили, используя 70\%-ный раствор этилового спирта и $0,1 \%$-ный раствор сулемы. В дальнейшем использовали методы культивирования и размножения растений in vitro и статистическую обработку полученных результатов. Результаты. Приведены результаты получения растений-регенерантов мискантуса из спящих почек, выделенных вместе с ризом из корней трехлетних растений Miscanthus $\times$ giganteus. Оптимальной для регенерации микропобегов оказалась питательная среда Мурасиге-Скуга, дополненная 6-бензиламинопурином и кинетином в концентрации 0,75 мг/л и 1,2 мг/л соответственно. При этом частота регенерации побегов была максимальной и составила $95 \%$, наблюдалось развитие основного побега и множественное побегообразование. Укоренение полученных побегов проводили на среде Мурасиге-Скуга с половинным содержанием макро- и микроэлементов без добавления регуляторов роста. Частота укоренения составляла 95,0-97,0 \%. Для адаптации мискантуса к условиям in vivo наилучшим оказался субстрат торф : песок : перлит в соотношении $2: 1$ : 1, при этом приживаемость растенийрегенерантов составляла 91 \%. Выводы. В результате проведенных исследований были изучены особенности морфогенеза в культуре in vitro растений мискантуса 


\section{MORPHOGENESIS OF MISCANTHUS × GIGANTEUS IN VITRO}

(Miscanthus $\times$ giganteus). Частота регенерации побегов составляла 90,0-100,0 \%, происходило развитие основного побега и множественное побегообразование с частотой 85,0-100,0 \%. Для адаптации мискантуса к условиям in vivo лучшим является субстрат торф : песок: перлит в соотношении $2: 1: 1$, приживаемость растений-регенерантов составила 91-95\%.

Ключевые слова: мискантус, энергетическая культура, регенерация, in vitro, морфогенез.

\section{REFERENCES}

1. Khivrych O, Kurylo V., Kvak V., Kaskiv V., Energy crops as raw material for biofuel. Propozytsia - Ukrainsky zhurnal z pytan agrobiznesu. 2011;(6):68-73. (in Ukrai-nian).

2. Roik MV, Hontarenko SM, Lashuk SO. Modern state of selection and registration of representatives of Miscanthus genus in Ukraine and in the world. Scient. works of the Institute of Bioenergy Crops and Sugar Beet. 2014;(21):249-53. (in Ukrainian).

3. Fuchylo YaD, Sbytna MV, Fuchylo OYa, Lytvyn VN. Experience and perspective of cultivating poplar ( $P O$ pulus sp. L.) in the southern Steppe of Ukraine. Scient. works of the Forest Academy of Sciences of Ukraine. 2009;(7):66-9. (in Russian).

4. Zinchenko V., Yashyn M. Energy of miscanthus. LesPromInform. 2011;6(80):77-86. (in Russian).

5. Yan J, Chen W, Luo FAN, Ma H, Meng A, Li X, Zhu M, Li S, Zhou H, Zhu W, Han B, Ge S, Li J, Sang T. Variability and adaptability of Miscanthus species evaluated for energy crop domestication. Global Change Biology Bioenergy. 2012;4(1):49-60. doi.org/10.1111/j.17571707.2011.01108.x.
6. Stewart JR, Toma Yo, Fernández F, Nishiwaki A, Yamada T, Bollerothe $G$. Ecology and agronomy of Miscanthus sinensis, a species important to bioenergy crop development, in its native range in Japan: a review. Global Change Biology Bioenergy, 2009;1(2):126-53. doi.org/10.1111/j.1757-1707.2009.01010.x.

7. Melnychuk MD, Dubrovin VO, Myronenko VG, Grygoruk IP, Polischuk VM, Holub GA, Targonya VS, Dragnev SV, Svystunova IV, Kukharets SM. Alternative energetics. Kyiv, Agrar Media Group, 2012:12-3. (in Ukrainian).

8. Anderson E, Arundale $R$, Maughan M, Oladeinde A, Wycislo A, Voigt T. Growth and agronomy of Miscanthus $\times$ giganteus for biomass production. Biofuels. 2011;2(1):71-87. doi: 10.4155/bfs.10.80.

9. Roik MV, Bekh NS, Kotsar MO. Obtaining Miscanthus $\times$ giganteus sprouts via clonal microreproduction. Scient. works of the Institute of Bioenergy Crops and Sugar Beet. 2013;19:15-9. (in Ukrainian).

10. Hontarenko SM, Lashuk SO. Obtaining Miscanthus sacchariflorus (Maxim.) Hack and Miscanthus sinensis plants invitroviaindirectmorphogenesis. Sortovyvchennia ta okhorona prav na sorty roslyn. 2017;13(1):12-9. doi: 10.21498/2518-1017.13.1.2017.97219.

11. Kim S, Kedong D, Chuansheng M. An efficient system for high-quality large-scale micropropagation of Miscanthus $\times$ giganteus plants. In Vitro Cell. Dev. Biol.Plant. 2012;48(6):612-9. doi 10.1007/s11627-012-9472-x.

12. Melnychuk MD, Kliachenko OL. Biotechnology in agrosphere. Kyiv, Agrar Media Group, 2014:247 p. (in Ukrainian).

13. Murashige TA, Scoog F. Revised medium for rapid, growth and bioassays with tobacco tissue cultures. Physiol. Plant. 1962;15(3):73-97. 